\title{
СУТНІСТЬ ЕКОНОМІЧНОЇ КУЛЬТУРИ ОСОБИСТОСТІТА ÏÏ РОЛЬ В ЕКОНОМІЧНІЙ СОЦІАЛІЗАЦІї
}

УдК: 316.6

\section{Зубіашвілі Ірина Костянтинівна}

Кандидат психологічних наук, старший науковий співробітник лабораторії організаиійної та соиіальної психологї̈ Інституту психології імені Г. С. Костюка Начіональної академії педагогічних наук України, м. Київ (Украӥна)

ORCID ID: https://orcid.org/0000-0003-3642-8159

Анотація. У статті аналізуються результати теоретичного дослідження сутності економічної культури особистості як найважливімої умови ї̈ економічної соціалізації. Проведене дослідження дало змогу визначити культуру як иілісну сукупність специффічно інтегрованих способів творчої діяльності, щуо створюють культурні цінності і яка є універсальною формою суспільного розвитку людини, детермінуючи ї̈ внутрішні та зовнішні соиіокультурні та соціосвідомі зв'язки з оточуючим світом. Визначено, щэо економічна культура - ие одна з особливих сфер культури, яка представляє собою, свого роду, проекцію економіки на сферу культури, хоча можна стверджувати, щзо культура є проекиію на сферу економіки. Сутнісні властивості економічної культури проявляються в тому, щзо по-перше, вони охоплюють тенденції, норми, які виникли із потреб економіки; по-друге, основним каналом впливу на економіку є не будь-яка поведінка, а передусім, економічна; по-третє, економічна культура більшою мірою орієнтована на управління поведінкою людей з метою підвищення матеріального благополуччя. Зазначено, щчо в умовах трансформації економічної системи України зростає роль та значення економічної культури суспільства в економічній соціалізайї населення, результатом якої має бути нова економічна культура особистості.

Ключові слова: культура, економічна культура, економічна сочүіалізація, особистість, цінності, норми.

Постановка проблеми. В контексті сучасних українських ринкових реформ економічна культура є важливим чинником еко- номічного і, в цілому, суспільного розвитку. Саме тому економічна культура привертає увагу дослідників різних напрямів: соціологів, 
культурологів, економістів, психологів.

3 1990-х рр. в українському суспільстві відбуваються фундаментальні економічні реформи, які супроводжуються процесами трансформації економічних відносин та економічної свідомості населення, що складають разом загальну трансформацію економічної культури сучасного українського суспільства. Дослідження цих процесів і, особливо, впливу трансформації економічної свідомості на трансформацію економічних відносин, $є$ однією 3 найактуальніших задач сучасної гуманітарної науки. Отже, увага гуманітаріїв до питань економічної культури об'єктивно зумовлена закономірностями сучасного етапу економічного та соціального розвитку суспільства. Як в суспільних, так і в економічних відносинах, нині важливими чинниками є такі ресурси, як моральність та духовність. Тому сучасні економічні реалії не можуть бути осмислені поза урахуванням їх соціокультурного контексту.

Дослідження сутності стану економічної культури суспільства та особистості дозволяє визначити можливі шляхи удосконалення економічної системи, оскільки саме результати економічної діяльності людини, іiі знання, здібності, свідомість, мислення, а також економічне середовище визначають перспективи соціально-економічного розвитку суспільства.

Аналіз останніх досліджень i публікацій. Теоретичну основу теоретичного дослідження сутності економічної культури особистості та іiі ролі в економічній соціаліза- ції складають розробки вітчизняних та зарубіжних вчених, які вивчали проблеми розвитку економічної культури особистості (О. Барабаш, М. Владика, I. Войтов, Т. Джагаєва, I. Ісаєв, О. Міщенко, В. Москаленко, Ю. Швалб та ін.), процес формування економічної культури суспільства (О. Улєдов, К. Улибін, В. Феофанов), типи монетарної культури особистості (в дослідженнях Є. Анікаєвої, Р. Белка, М. Валлендорфа, О. Дейнеки, В. Ільїна, Д. Літвиненка, А. Фернама, М. Шкрабця та ін.); соціально-демографічні чинники формування монетарних уявлень у дітей (Г. Маршалл, Л. Магрудер, Т. Мельничук, Р. Саттон, М. Сігал, А. Фернам, А. Фенько, Д. Швальб та ін.),

Мета статті - на основі теоретичного дослідження визначити сутність економічної куль-

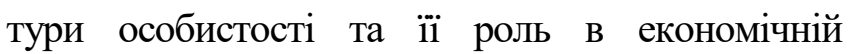
соціалізації.

Виклад основного матеріалу і результатів дослідження.Для визначення сутності економічної культури особистості методологічну значущість має аналіз сутності культури, історії розвитку теорії культури, іiї трактування в сучасних гуманістичних і соціальних науках, що допоможе більш глибокому аналізу виокремленого нами феномену. Така методологія дослідження передбачає використання культурологічного підходу в рамках загального розуміння культуры, включаючи локальний аналіз в сфері філософії, соціології, психології, культурології, педагогіки та інших 
наук.

У науковій літературі існує багато визначень поняття «культура», яке є складним міждисциплінарним, загальнометодологічним поняттям. Під культурою розуміється історично визначений рівень розвитку суспільства і людини, виражений в типах і формах організації життя та діяльності людей, а також в матеріальних і духовних цінностях, що створюються ними.

У культурі розвивається духовний світ людини, ïi «сутнісні сили» (здібності, потреби, світогляд, знання, уміння тощо). Саме цим культура $є$ мірою реалізації та розвитку людини в процесі їі соціальної діяльності. Створюючи матеріальний або духовний продукт, людина опредмечує в ньому саму себе, і не лише свою суспільну сутність, але тією чи іншою мірою - свою індивідуальність [ 4 ].

Індивідуальні відмінності в культурі можуть проявлятися в різному ступені засвоєння індивідом настанов, цінностей та ін. Як соціальний конструкт культура посилює ту поведінку, яку програмує [ 6;7 ].

Підкреслімо, що оволодіння культурою потребує активності з боку самої людини та завершується формуванням індивідуальної культури. Особистістю починається та завершується процес культурного відтворення, тому що людина створює та використовує культурні цінності. Індивідуальна культура об'єктивується в характеристиках поведінки та діяльності особистості, що проявляється у різ- них формах взаємодії людей. У цілому, процес долучення особистості до культури відбувається за двома напрямами: від суспільства до особистості та від особистості - до суспільства.

Особистісна культура індивіда - це сукупність його особистих зразків поведінки, його методів діяльності, продуктів цієї діяльності, його ідей та думок. Ступінь культурності людини визначається виходячи 3 норм та цінностей соціокультурного оточення. Єдиного поняття культурнорозвиненої людини не існує, але існують формальні критерії індивідуального рівня культурного розвитку: міра освіченості, об'єм соціокультурного досвіду, способи його реалізації, оволодіння відповідними нормами поведінки тощо.

Сучасне філософське-соціологічне i психолого-педагогічне осмислення культури допоможе більш глибокому аналізу цього феномену. Використання культурологічного підходу дозволить в широкому діапазоні соціуму розглянути сучасні культурологічні течії в плані виокремлення та синтезування знань, накопичених внутрі різних наукових напрямів. І оскільки культура - складне соціальне явище, то природно, що існує багато підходів до її дослідження та їх відображення в науково-теоретичних поглядах сучасних авторів.

У сучасних гуманістичних і соціальних науках поняття «культура» трактується по-різному, тому і відрізняються визначення культури у цих науках. Філософи розгляда- 
ють культуру з точки зору іï загальної сутності, як людське творіння в системі «Людина Світ». Соціологи та культурологи цікавляться передусім духовними продуктами, що створено людьми. У соціологічних визначеннях культури називають такі їі складові як ідеї, що передаються з покоління в покоління; пов'язані $з$ ними системи цінностей, які в свою чергу визначають поведінку індивідів і груп, їх способи мислення і сприймання елементів культури, зумовлено різними чинниками [ 12 ].

Психологів культура цікавить як чинник впливу на становлення особливостей індивідуально-психологічних характеристик людини, як елементи культури відображаються у свідомості людей. Так, американський психолог Г. Триандіс, вивчаючи суб'єктивну культуру, визначив характерні для неї способи, завдяки яким іiі члени пізнають створену ними частину людського оточення: те, як вони категоризують соціальні об'єкти, які зв'язки виокремлюють між категоріями, а також норми, ролі і цінності, які вони визнають своїми. В такому розумінні культура охоплює всі уявлення, ідеї і вірування, які об'єднують певний народ i здійснюють безпосередній вплив на поведінку і діяльність його членів. Етнопсихологами досліджуються відмінності між культурами. Досліджуються також і культурні універсалії, тобто риси, які властиві всім народам [ там само ]. Основною галуззю досліджень у соціальній психології, на думку С. Московічі, $\epsilon$ вивчення культурних процесів
[ 13 ].

Погляди на природу культури, на іiі значущість змінювалися 3 розвитком наукової думки в психології. Складність визначення цього поняття полягає в тому, що воно носить міждисциплінарний характер і в деяких теоретичних роботах так і не отримало визначення як категорія психологічна [ 18 ].

Проблема ролі культури постала перед психологічною наукою як ніколи гостро в наш час. Дослідники відмічають, що такі теоретичні напрями психології у США, як біхевіоризм, когнітивізм, символічний інтеракціонізм, знаходячись на позиціях методологічного індивідуалізму, пояснюють феномени культури, цінності, ціннісні орієнтації.

Наприклад, перспектива аналізу соціальної настанови як ставлення до певної культури була ключовою в концепції У. Томаса i С. Знанецького ще на початку 20 сторіччя. Coціальна настанова представлена дослідниками як психологічне переживання індивідом значущості або цінності соціального об'єкту, яка функціонує одночасно як елемент психологічної структури особистості та як елемент соціальної структури, оскільки зміст психологічного переживання визначається зовнішніми, локалізованими в соціумі об'єктами. Настанова в цієї концепції - психологічний процес, який відноситься до соціального світу, передусім, у зв'язку із соціальними цінностями [21].

Іншими вченими було проведено дослідження впливу культури на мислення і когні- 
тивні процеси: порівняльний аналіз різних культур підтвердив реальність виникаючих у суспільстві змінних, які впливають на візуальне сприйняття. Було проведено дослідження взаємодії культури і мислення, культури i сприйняття [20].

Що стосується становлення поняття «культура» у вітчизняній та російській психології, то вже у дореволюційний період багато проблем - роль мови, емоції и переживання як прояв ставлення, значущість соціального обміну, зв'язок психології та ідеології - вирішувалися задовго до їх розробки у США та Західній Свропі [ 8 ]. Наприклад, К. Кавелін запропонував метод дослідження духовної сторони людини за продуктами духовної діяльності - пам'ятниками культури, віруванням, фольклору [там само]. Працю С. Франка «Духовні основи суспільства : Введення у соціальну філософію» вчені називають методологічною основою сучасної психології культури [ 19 ].

СРСР була єдиною країною, у якої версія «другої» психології В. Вундта отримала відомість. У зв'язку з цим дослідники виокремлюють концепції, розроблені Л. Виготським, А. Лурія і О. Леонтьєвим. Їх праці надали культурній психології В. Вундта фундаментальну основу. На думку М. Коула, якщо б їх підхід запанував, уся психологія розглядала б культуру поряд з біологією і соціальними взаємодіями як центральний чинник [18 ].
Л. Виготський створив культурноісторичний напрям в психології, який став фундаментальною основою досліджень культури науковцями протягом всього двадцятого сторіччя. Центральна ідея цієї психології полягає в тому, що структура і розвиток психічних процесів людини створюється іiі предметною діяльністю, яка опосередкована культурою суспільства в її історичному розвитку [ 12 ].

Представники сучасних різних теоретичних шкіл психології усвідомлюють значущість феномену культури. Слід зазначити, що у психології поняття «культура» практично не визначається i, як правило, переноситься з поріднених гуманітарних наук. У той же час багато дослідників підкреслюють, що під культурою розуміється система різних суспільних відносин, у яку є включений суб'єкт і яка формує суб'єкта (повідомляє йому знання, навички, поняття про норми і цінності та виступає ареною його власної діяльності) [ 10 ].

На думку дослідників (I. Сушкова, М. Косолапова, А. Журавльова, Т. Мельничук), цей підхід найбільш відповідає дослідженню взаємодії культури та системи індивідуальних цінностей, тому що головним аспектом соціально-психологічних відносин виступає їх ціннісна сторона. Отже, досліджуючи важливі характеристики культури, ми маємо досліджувати іï ціннісну структуру та взаємозв'язок із системами індивідуальних цінностей конкретних людей, з яких спільнота складається. Культура розуміється як феномен, через 
який у свідомості особистості представлена система цінностей спільноти [ 15;16 ].

В. Москаленко також зазначає, що у формах культури як певних формах взаємин, людина немов бачить саму себе, свої сутнісні сили, які сформувались всім ходом історії. Привласнюючи предмети культури, людина отримує змогу реалізувати в собі людську сутність. Розвиток культури визначається, насамперед, наступністю, збереженням усіх позитивних цінностей, які знаменують собою безперервність суспільного прогресу [ 12 ].

Отже, традиційно сутнісне ядро культури включає в себе константну складову цінності, що є соціально схваленою системою еквівалентностей різної природи, які поділяються усіма членами конкретного суспільства та транслюються наступному поколінню.

\section{У більшості концепцій культури}

обгрунтовується, що завжди проблема культури - це проблема взаємодії людей, зокрема такої взаємодії, у якій люди «створюють», формують один одного. Так, важливими для нашого дослідження стали ідеї інтеграційної теорії культури

П. Сорокіна, який у розумінні культури акцентує увагу на взаємодії людей. Для нього культура - це сукупність значень, цінностей і норм, якими володіють взаємодіючі особи та об'єктивують, соціалізують і розкривають ці значення [ 4 ].

Згідно $з$ підходом української школи філософії культури (В. Андрущенко, Л. Гу- берський, В. Іванов, М. Михальченко, В. Шинкарук, О. Яценко та ін.), культура постає в узагальнених характеристиках як форма, результат, спосіб зв'язку людини з дійсністю, утвердження людини як прояв і утвердження сутнісних сил людства. Культура - це специфічний спосіб діяльності людини, який включає в себе спосіб регуляції, збереження, відтворення і розвитку суспільства. Виражаючи форму існування людської практики, спосіб зв'язку людей в процесі сумісної діяльності, культура причетна до всіх рівнів виявлення соціальності. Вона може розглядатися у відповідності зі сутністю історичного процесу, в якості загального його визначення. Вона може розглядатися також з боку характеристик особистості, які визначають іiі здатності як суб'єкта історії, сумісної діяльності, спільного виробництва [ 12 ].

Іноді термін «культура» розуміють як синонім слова «цивілізація», але між ними існує принципова різниця, яку підкреслює I. Ільїн : «Культура є явище внутрішнє та органічне : воно охоплює саму глибину людської душі та складається на шляхах живої, таємничої доцільності. Цим вона відрізняється від цивілізації, яка може засвоюватись зовнішньо та поверхово і не потребує всієї повноти душевної участі» $[7$, с. 4].

У понятті «культура» фіксується історична своєрідність форм життєдіяльності, як на різних етапах розвитку суспільства, так і в рамках певних епох, спільнот. Культуру мож- 
на розуміти як певний соціальний механізм, який відтворює ті чи інші еталони і норми поведінки людей. Культура включає всю сукупність зв'язків індивідів у всіх сферах реальності (економічній, політичній, правовій, моральнісній, екологічній, релігійній, естетичній тощо), які є тим культурним середовищем, що визначає стратегії поведінки людини, способи діяльності, задає індивідам як суб'єктам соціальної діяльності їх ставлення до світу в цілому. Такий погляд на культуру передбачає розглядати iї особливості як характеристику форм, які мають людинотворчий характер, а процес соціалізації особистості як інтеріоризацію цих форм у внутрішні детермінанти процесу соціалізації, результатом якого є набуття психологічних характеристик, що відображають ступінь розвитку людини як особистості.

Розвиток людини в культурі, на думку В. Семенова, проявляється в таких формах : у культурній, культурностворюючий діяльності; у освоєнні культурної реальності та оволодінні накопиченим людством культурним багатством; у особистісному прояву культури, тобто в реалізації людиною в діяльності освоєних нею культурних досягнень, знань, навичок, умінь. 3 позиції діяльнісного підходу, особистість - це одночасно і суб'єкт і об'єкт культури, тому що вона іiї створює та нею формується [ 17 ].

Отже, існує багато визначень культури, і дискусії з питання про сутність культури як суспільного феномену тривають вже довгий час, проте головне, в чому сходяться більшість дослідників теорії культури - це визначення іï «людинотворчою» стороною соціально-історичної життєдіяльності людей. Культура, характеризуючи суспільство в цілому, виступає його своєрідним «зрізом», який показує наскільки та чи інша суспільна система, або окрема сфера суспільства чи суспільна спільнота сприяє (або перешкоджає) розвитку особистості.

Для нашого дослідження важливим $€$ твердження В. Москаленко, що оскільки людина не може бути зрозумілою без співвідношення з їі роллю у суспільній життєдіяльності, із суспільними відносинами, з колективними діями, то зрозуміло, що категорія «культура» має найважливіше значення для розкриття сутності процесу соціалізації людини. Саме в цьому автор вбачає психологічний аспект дослідження культури і в цьому аспекті визначає культуру як формотворення (форма, яка створює) людини [ 12 ].

Дослідники вважають культуру є одним із макрочинників соціалізації, в процесі якої особистість засвоює соціальний досвід, перетворює його у власні цінності, імперативи, настанови, орієнтації, виконує та розширює репертуар соціальних ролей, а також відтворює соціальні норми та правила [ 5 ].

Отже, проведений нами науковий аналіз поняття «культура» дає змогу зробити висновок : у якому би контексті не розглядався цей феномен, він завжди вказує на процес 
створення людиною цінностей цивілізації; на процес розвитку, перетворення, поліпшення предметно-матеріальної та духовно-творчої діяльності як дійсності, що оточує, так і самої себе як особистості.

У загальному вигляді культура може бути визначена як цілісна сукупність специфічно інтегрованих способів творчої діяльності, яка створює культурні цінності і яка $є$ універсальною формою суспільного розвитку людини, детермінуючи їі внутрішні та зовнішні соціокультурні та соціосвідомі зв'язки з оточуючим світом.

Принципове значення для нашого дослідження має те, що культура не лише зберігає, транслює досвід від покоління до покоління, але головне - акумулює та генерує нові програми діяльності, поведінки та спілкування, які, реалізуючись у відповідних видах і формах людської активності, породжують реальні зміни у житті конкретного індивіда, соціальної групи, суспільства [ 4 ].

У сучасній вітчизняній та зарубіжній літературі велика увага приділяється взаємозв'язку економічних та культурних аспектів у цілому. Економічна культура - це одна з особливих сфер культури, яка представляє собою, свого роду, проекцію економіки на сферу культури, хоча можна стверджувати, що культура є проекцію на сферу економіки [ 3 ].

У 80-ті роки 20-го сторіччя економіст П. Буніч, психолог О. Кітов і філософ В. Фофанов поставили питання про виокремлення особливої галузі знання, що лежить на стику економіки та психології, сутність якої полягає в дослідженні закономірностей розвитку економічної свідомості. В рамках цієї проблеми стало розглядатися і поняття економічної культури [ там само].

У західній та вітчизняній літературі icнує декілька визначень економічної культури, що свідчить про складність та багатогранність цього феномену. Традиційний підхід зводить економічну культуру до економічної свідомості в іiї стійких формах і стереотипах. При цьому, в якості визначаємих часто фіксуються різні елементи економічної свідомості, такі як економічні цінності, традиції, норми, орієнтації тощо.

Цікавою в цьому плані є позиція В. Радаєва, який особливість економічної культури бачить в тому, що вона пов'язана з людською суб'єктивністю і тому виступає не економічним процесом, а комплексом уявлень певної спільноти про економіку [16]. На думку автора, економічну культуру можна трактувати в якості ціннісно-нормативної системи, цінності якої поділяються більшістю членів економічної спільноти. Ціннісний зміст економічної культури виокремлюється і в багатьох інших працях.

Сутнісні властивості економічної культури проявляються таким чином : по-перше, вони охоплюють тенденції, норми, які виникли із нужд економіки; по-друге, основним каналом впливу на економіку є не будь-яка по- 
ведінка, а передусім, економічна; по-третє, економічна культура більшою мірою орієнтована на управління поведінкою людей з метою підвищення матеріального благополуччя $[15 ; 17]$.

Виходячи із сутності економічної культури можна визначити їі функції: світоглядна - формування загального уявлення про економіку, про економічну діяльність; трансляційна - передача 3 минулого в майбутнє соціальних цінностей, норм, еталонів поведінки, що склалися в сфері виробництва та розподілу в галузі економічної діяльності; селекційна - відміна морально застарілих цінностей, норм, еталонів поведінки; інноваційна - оновлення соціальних цінностей, норм, еталонів поведінки та запозичення їх 3 інших прогресивних культур; гуманістична: формування активної життєвої позиції людини, духовний прогрес, перетворення світу; аксіологічна - зв'язок різних цінностей між собою, із соціальними і культурними чинниками та структурою особистості; адаптаційна - взаємодія особистості або соціальної групи із соціальним середовищем; стабілізаційна: формування безконфліктного розвитку суспільства [ там само ].

У процесі функціонування економічна культура активно впливає на стан та рівень розвитку людини, на формування системи іiі економічних цінностей, норм економічної поведінки та форм участі в економічному житті суспільства.
Формування та розвиток економічної культури характеризується суперечливістю та нестабільністю. Це пояснюється тим, що цей вид культури відображає особливості конкретного економічного процесу, тих соціальних зв'язків та відносин, які існують в суспільстві. При зміні реалій закономірно змінюється і культура. Однак, при цьому відбувається не лише пряма кореляція з об'єктивними суспільними процесами, але й з внутрішнім саморухом економічної культури, розвиток економічних традицій та новацій [16].

ановимся на понятии и сущности экономической культуры и ценностей.

Экономическая культура - это не только часть или «вид» культуры наряду с другими

eе видами (политической, правовой, культурой общения, культурой питания, физи

ческой культурой), но это также «проекция» всей культуры на сферу экономики и

экономических отношений, потому что вся культура, все ее ценности и нормы так или

иначе проявляются, работают и в области экономики.

Согласно определению И.Г. Минервина, «экономическая культура - это совокупность традиционных и инновационных знаний, социальных и духовных ценностей и норм, ценностей, регулирующих эко- 
номическое поведение людей и их трудовую дея-

тельность» [5] $\square$ (Minervin, 2011). Данное определение экономической культуры состоит

из трех частей, объединяющих основные подходы к ней:

a) аксиологический (аксиология - наука о ценностях);

б) понимание экономической культуры как «социальной памяти», ее фрактальная

структура, обеспечивающая связь времен, преемственность поколе

ановимся на понятии и сущности экономической культуры и ценностей.

Экономическая культура - это не только часть или «вид» культуры наряду с другими

eе видами (политической, правовой, культурой общения, культурой питания, физи-

ческой культурой), но это также «проекция» всей культуры на сферу экономики и

экономических отношений, потому что вся культура, все ее ценности и нормы так или иначе проявляются, работают и в области экономики.

Согласно определению И.Г. Минервина, «экономическая культура - это совокупность традиционных и инновационных знаний, социальных и духовных ценностей и норм, ценностей, регулирующих экономическое поведение людей и их трудовую дея тельность» [5] $\square$ (Minervin, 2011). Данное определение экономической культуры состоит

из трех частей, объединяющих основные подходы к ней:

a) аксиологический (аксиология - наука о ценностях);

б) понимание экономической культуры как «социальной памяти», ее фрактальная

структура, обеспечивающая связь времен, преемственность поколе

ановимся на понятии и сущности экономической культуры и ценностей.

Экономическая культура - это не только часть или «вид» культуры наряду с другиМИ

еe видами (политической, правовой, культурой общения, культурой питания, физической культурой), но это также «проекция» всей культуры на сферу экономики и

экономических отношений, потому что вся культура, все ее ценности и нормы так или иначе проявляются, работают и в области экономики.

Согласно определению И.Г. Минервина, «экономическая культура - это совокупность традиционных и инновационных знаний, социальных и духовных ценностей и норм, ценностей, регулирующих экономическое поведение людей и их трудовую дея $-$ 
тельность» [5] $\square($ Minervin, 2011). Данное определение экономической культуры состоит

из трех частей, объединяющих основные подходы к ней:

a) аксиологический (аксиология - наука о ценностях);

б) понимание экономической культуры как «социальной памяти», ее фрактальная

структура, обеспечивающая связь времен, преемственность поколе

ановимся на понятии и сущности экономической культуры и ценностей.

Экономическая культура - это не только часть или «вид» культуры наряду с другими

еe видами (политической, правовой, культурой общения, культурой питания, физической культурой), но это также «проекция» всей культуры на сферу экономики и

экономических отношений, потому что вся культура, все ее ценности и нормы так или иначе проявляются, работают и в области экономики.

Согласно определению И.Г. Минервина, «экономическая культура - это совокупность традиционных и инновационных знаний, социальных и духовных ценностей и норм, ценностей, регулирующих экономическое поведение людей и их трудовую дея тельность» [5] $\square($ Minervin, 2011). Дан- ное определение экономической культуры состоит

из трех частей, объединяющих основные подходы к ней:

а) аксиологический (аксиология - наука о ценностях);

б) понимание экономической культуры как «социальной памяти», ее фрактальная

структура, обеспечивающая связь времен, преемственность поколе

Економічну культуру розглядають в широкому і вузькому смислі. Економічна культура в широкому розумінні - це опредметнені матеріальні результати праці суб'єктів економічної діяльності. Економічна культура у вузькому розумінні слова - це сукупність цінностей, норм, стереотипів як особистісного, так й інституціонального характеру, що $є$ регуляторами поведінки суб'єктів економічної діяльності, їхніх стратегій і взаємин у процесі економічної діяльності.

У контексті нашого дослідження слід зазначити, що на основі економічної культури суспільства відбувається становлення економічної культури особистості.

Поняття «економічна культура» відображає складну взаємодію економіки і культури, як відносно самостійних сфер людського буття. Провідним в понятті «економічна культура» $є$ «культура», як феномен, який знаходиться в діалектичному взаємозв'язку з економікою [10].

У загальному плані економічна культу- 
pa суспільства представляє собою комплекс елементів і явищ культури, стереотипів економічної свідомості, мотивів поведінки, економічних інститутів, що забезпечують зберігання та відтворення економічного життя, а також його покращення [ 5].

У понятті«економічнакультура особистості» відображається економічна культура на рівні окремого індивіда. В ньому розкривається певне місце людини в економічній сфері суспільства, яке детермінується, передусім, іiі соціальними якостями, що забезпечують їй це місце. На цьому рівні культура конкретизується як економіко-психологічні властивості індивіда, що забезпечують йому певний статус в економічній сфері суспільства, визначають спосіб та рівень його економічної діяльності [ 12].

Економічна культура особистості - це індивідуальний спосіб освоєння економічної системи суспільства та економічної реальності або спосіб інтеграції особистості в економічну систему суспільства, індивідуальний тип економічної діяльності [17].

Економічна культура особистості, ïi становлення та розвиток знаходяться під безпосереднім впливом (стихійним або цілеспрямованим) не лише суспільного життя в цілому але й економічної культури суспільства. Цей вплив може бути як позитивним, так і негативним. Воля, настанови, ціннісні орієнтації особистості визначають її вибір.

Таблиия 1.

\section{Рівні засвосння ієрогліфічних компетенцій студентами ЕГ та КГ до та після експерименту}

\begin{tabular}{|c|c|c|c|c|c|c|c|c|c|}
\hline \multirow{3}{*}{ Види компетенцій } & \multirow{3}{*}{ Рівні } & \multicolumn{4}{|c|}{ До експерименту } & \multicolumn{4}{|c|}{ Після експерименту } \\
\hline & & \multicolumn{2}{|c|}{$\begin{array}{c}\mathrm{E} \Gamma \\
(\mathrm{n}=26)\end{array}$} & \multicolumn{2}{|c|}{$\begin{array}{c}\mathrm{K} \Gamma \\
(\mathrm{n}=24)\end{array}$} & \multicolumn{2}{|c|}{$\begin{array}{c}E \Gamma \\
(n=26)\end{array}$} & \multicolumn{2}{|c|}{$\begin{array}{c}\mathrm{K} \Gamma \\
(\mathrm{n}=24)\end{array}$} \\
\hline & & Абс. & $\%$ & Абс. & $\%$ & Абс. & $\%$ & Абс. & $\%$ \\
\hline \multirow{3}{*}{ Лінгвістична } & Вис. & 3 & 11,5 & 4 & 16,6 & 7 & 26,9 & 4 & 16,6 \\
\hline & Cep. & 16 & 61,5 & 13 & 54,1 & 15 & 57,6 & 14 & 58,3 \\
\hline & Низьк. & 7 & 26,9 & 7 & 29,1 & 4 & 15,3 & 6 & 25 \\
\hline \multirow{3}{*}{ Соціокультурна } & Вис. & 4 & 15,3 & 4 & 16,6 & 9 & 34,6 & 5 & 20,8 \\
\hline & Cep. & 14 & 53,8 & 12 & 50 & 13 & 50 & 13 & 54,1 \\
\hline & Низьк. & 8 & 30,7 & 8 & 33,3 & 4 & 15,3 & 6 & 25 \\
\hline \multirow{3}{*}{ Стратегічна } & Вис. & 3 & 11,5 & 3 & 12,5 & 7 & 26,9 & 4 & 16,6 \\
\hline & Cep. & 12 & 46,1 & 12 & 50 & 14 & 53,8 & 13 & 54,1 \\
\hline & Низьк. & 11 & 42,3 & 9 & 37,5 & 5 & 19,2 & 7 & 29,1 \\
\hline \multirow{3}{*}{$\begin{array}{l}\text { Інформаційно- } \\
\text { аналітична }\end{array}$} & Вис. & 6 & 23 & 5 & 20,8 & 9 & 34,6 & 6 & 25 \\
\hline & Cep. & 10 & 38,4 & 10 & 41,6 & 13 & 50 & 11 & 45,8 \\
\hline & Низьк. & 10 & 38,4 & 9 & 37,5 & 4 & 15,3 & 7 & 29,1 \\
\hline \multirow{3}{*}{$\begin{array}{c}\text { Загальна ієрогліфічна } \\
\text { компетентність }\end{array}$} & Bис. & 4 & 15,3 & 3 & 12,5 & 8 & 30,7 & 4 & 16,6 \\
\hline & Cep. & 13 & 50 & 13 & 54,1 & 13 & 50 & 14 & 58,3 \\
\hline & Низьк. & 9 & 34,6 & 8 & 33,3 & 5 & 19,2 & 6 & 25 \\
\hline
\end{tabular}


Відповідно до економічної культури суспільства, на рівні особистості економічна культура включає в себе індивідуальні складові:

- економічну свідомість (розвинену тією чи іншою мірою), яка об'єднує в собі почуття, уявлення, погляди, також знання норм економічного буття, настанови та мотиви поведінки; а також способи діяльності в економічній сфері, позитивний характер якої залежить від вольового вибору та настанов особистості [3].

Економічна культура особистості, iii становлення та розвиток також залежать від соціально-історичного контексту, рівня суспільного виробництва, традицій, менталітету. Однак, зазначимо, що система освіти є найважливішим соціокультурним регулятором економічної культури особистості та суспільства.

Між економічною культурою суспільства та економічною культурою особистості існує складний зв'язок і взаємна залежність, що проявляється, передусім, у слідуванні особистості принципам економічної культури суспільства. Економічна культура особистості може відповідати економічній культурі суспільства, опереджати іiі, але може й відставати від неї, заважати іiї розвитку [ 4 ].

На основі теоретичного аналізу точки зору різних вчених стосовно економічної культури особистості, можна зробити висновок, що вони виокремлюють головні основи економічної культури, які підтверджують тісний взаємозв'язок між культурою суспільства та культурою особистості :

- економічне мислення, пов'язане 3 ціннісними орієнтаціями, готовністю до пошуку нових рішень, до зміни сфери діяльності та ін.;

- економічна поведінка, спрямована на досягнення поставленої мети;

- економічна діяльність, що реалізується у відповідності із соціально-значущими задачами та планами [ 3 ].

Дослідники [4; 16] пропонують основні критерії економічної культури особистості, які характеризуються високим рівнем володіння економічними знаннями та вміннями; здатністю орієнтуватися в економічних ситуаціях; гнучкістю мислення; прагненням до самореалізації; володінням високою моральнісТю.

Отже, економічні культура є процесом освоєння особистістю економічної сфери культури суспільства, iї норм і цінностей, системи поглядів і знань, способів діяльності, що дозволяє їй функціонувати в якості повноправного члена суспільства.

В умовах трансформації економічної системи України зростає роль та значення економічної культури суспільства в економічній соціалізації населення, результатом якої має бути нова економічна культура особистості.

Зазначимо, що в широкому розумінні економічна соціалізація - це процес входжен- 
ня індивіда в економічну сферу суспільства, формування у нього економічного мислення, процес інтеріоризації економічної реальності, що включає пізнання економічної дійсності, засвоєння економічних знань, формування економічних уявлень, знання економічних категорій, засвоєння і реалізацію ролей і навичок економічної поведінки.

Метою економічної соціалізації є вироблення адекватних і гармонійних уявлень про економіку, знання економічних категорій, розвиток навичок економічної поведінки. Варто відмітити, що цілі й задачі економічної соціалізації багато в чому збігаються з цілями і задачами економічного виховання, оскільки останнє $є$ цілеспрямованою формою економічної соціалізації.

Отже, економічна соціалізація - безперервний динамічний процес економікопсихологічного розвитку особистості, який відбувається як активний внутрішньомотивований процес прийняття людиною досвіду економічної діяльності, норм і традицій економічної культури.

Науковий аналіз літератури дозволяє виокремити три аспекти цього феномену економічний, психологічний, педагогічний. Ми, як й інші вчені (О. Вяткін, Н. Дембицька, А. Журавльов, О. Козлова, О. Лавренко, В. Москаленко) розглядаємо економічну соціалізацію як психологічний феномен, як розглядання індивідуальності особистості в контексті їі взаємодії із соціумом, того, як особистість обирає для себе представлені суспільством зразки поведінки, ціннісні орієнтації, а потім відтворює їх в економічній діяльності.

Дослідники виокремлюють культурологічні аспекти економічної соціалізації. 3 цієї точки зору, економічна соціалізація відбувається як процес оволодіння людиною культурного спадку, соціально значимих економічних цінностей. В. Москаленко вважає, що економічна соціалізація людини визначається рівнем її економічної культури. На думку вченої, формування економічної культури, а як наслідок, і процес економічної соціалізації, має відбуватися через розвиток усіх іiі складових [ 12 ].

Для нашого дослідження є важливою також думка Г. Васильової про те, що рівень економічної культури особистості корелятивен та визначається іiі соціалізованістю, що пов'язано зі ступенем розвитку здатності особистості до відповідального вибору, цілеспрямованісті, життєвої креативності [ 4 ].

Як зазначають дослідники [ 9; 12 ], процес соціалізації особистості здійснюється в активній діяльності та спілкуванні. Характер цього процесу визначається включенням особистості в соціальну практику суспільних відносин та здійснюється за допомогою соціальних контактів 3 оточуючими людьми і цими суспільними групами, які вони складають. За допомогою цих контактів здійснюється соціальне пізнання, засвоєння певних норм, позицій і ролей; створення системи ціннісних на- 
станов, орієнтацій, включення в активну творчу діяльність.

Отже, соціалізація, є однією з форм залучення до культури, оскільки полягає у привласненні особистістю норм, цінностей, ідеалів суспільства. Сутнісний зміст соціалізації розкривається на перетинанні таких іiі процесів як адаптація, інтеграція, саморозвиток та самореалізація. Діалектична їх єдність забезпечує оптимальний розвиток особистості протягом всього життя людини у взаємодії з оточуючим середовищем. У цьому смислі дослідження культури означає вивчення складного суспільного процесу освоєння соціокультурного середовища.

На сучасному етапі розробки проблеми економічної соціалізації підростаючого покоління, у зв'язку з ускладненням сфер суспільного життя, з'являється необхідність визначення впливу економічної культури на процес економічної соціалізації особистості.

Багато уявлень, мотивів поведінки людини сформовані культурою, в якій відбувається іiї соціалізація, що й визначає специфіку багатьох економічних, політичних та соціальних процесів, які відбуваються на групових та індивідуальних рівнях [ 9 ].

Згідно О. Белінської та О.Тихомандрицької, серед спектру механізмів економічної соціалізації (інкультурація, інтерналізація, адаптація, конструювання соціальності), потрібно звернути увагу саме на інкультурацію, яка $є$ впливом і включенням чин- ників культури в соціальну поведінку особистості [2 ].

Виходячи $з$ концепції М. Херсковиц, в процесі інкультурації індивід засвоює притаманні економічній культурі світорозуміння та поведінку, в результаті чого формується його когнітивна, емоційна та поведінкова схожість 3 членами даної економічної культури [там само].

Процес інкультурації починається з моменту народження та відбувається у сім’ї під управлінням батьків і старших родичів на власному досвіді. Результатом процесу інкультурації є сама людина, яка компетентна в своїй культурі [ $3 ; 15$ ]. Виокремлюють два етапи інкультурації, єдність яких забезпечує розвиток та функціонування культури.

По - перше, це - дитинство. Результатом процесу інкультурації може бути безумовне освоєння економічної культури новим поколінням (з невеликими відмінностями між дітьми та батьками), але також може бути i невдалий результат (діти цілковито не схожі на батьків) [ $3 ; 15$ ].

По - друге, це - зрілість. Інкультурація в зрілому віці переривчаста, вона стосується лише окремих «фрагментів» культури - нових ідей, відкриттів. Головною особливістю цього етапу є допустимість для людини в тій чи іншій мірі приймати або не приймати те, що запропоновоно культурою, можливість дискусії. Саме в період зрілості інкультурація відкриває шлях до змін та сприяє тому, щоб стабільність 
не трансформувалася в застій, а економічна культура не лише зберігалася але й розвивалася [ 20 ].

Деякі дослідники соціалізації також використовують поняття інкультурації. Наприклад, М. Мід під соціалізацією має на увазі соціальне научиння, а інкультурацію розуміє як реальний процес научиння, який відбувається в специфікі культури [ 11 ].

Отже, сучасні дослідження економічної соціалізації особистості так чи інакше пов'язані з інкультурацією.

У процесі економічної соціалізації особистості відбувається засвоєння основних складових елементів економічної культури, до яких відносяться [ 7 ] :

- економічні цінності - загальноприйняті уявлення відносно цілей, до яких має прагнути людина в економічній діяльності. Вони функціонують у формі ідеалу, основних принципів мислення та є ідеальними критеріями оцінки економічних подій, явищ, процесів. Економічні цінності містять переваги відносно таких понять, як багатство, гроші, засоби отримання доходів, а також відносно більш абстрактних категорій, таких як капіталізм, соціалізм, індивідуалізм, економічна свобода, рівність; економічні ідеали - це економічні уявлення про досконалість у сфері економічного життя. Тому вони повністю можуть бути досягнені, але представляють собою мрію та зразок, до якого прагнуть люди;
- економічні норми - загальні шаблони, які регулюють економічну поведінку в певному напряму. Це система очікувань того, як люди повинні діяти в економічній сфері;

- економічні стереотипи - спрощенні, схематичні, деформовані та ціннісноорієнтовані уявлення про економічні об'єкти, явища, процеси;

- економічні міфологеми - статичний образ, засновані на віруваннях та, які дозволяють систематизувати та інтегрувати факти і події, не зовсім зрозумілі за смислом, структурувати колективні уявлення про теперішнє та майбутнє.

Економічні реформи в нашій країні пов'язані з виникненням нових економічних цінностей і норм, їх укорінення в свідомості та поведінці людей. Те, що не усвідомлюється в культурі, стає причиною конфліктів, оскільки сприймається як чинник дезорганізації суспільства. Тому, будь-які зміни повинні супроводжуватися відповідним культурним забезпеченням. Культурні зміни передують економічним, створюючи для них підгрунтя та мотивацію. Удосконалення економічних відносин передбачає становлення нової економічної свідомості особистості та поведінкових зразків.

Пов’ язуючи економічну соціалізацію 3 процесом становлення економічної культури особистості, слід зазначити, що культура здатна переносити цінності та настанови людей із духовної сфери в матеріальну, втілювати 
цінності в дійсність. При цьому важливим $є$ те, що цінності, які регулюють поведінку та діяльність особистості в значущих економічних ситуаціях, будуть впливати на відносини суб'єктів економіки один з одним і в цілому на економічну ситуацію в країні. У наш час все більше значущим стає не творча праця, а власність і багатство, незалежно яким способом вони були отримані. Потрібно звернути увагу на забезпечення морального змісту багатьох цінностей ринку, формування системи цінностей економічних відносин, що спираються на загальнолюдські, щоб уникнути криміналізації економіки та економічних відносин, так як система цінностей, які входять до економічної культури, визначає процес економічної соціалізації [ 1 ].

Цінності культури є значущим індикатором для відслідкування процесів соціальних та індивідуальних змін і визначають вектор соціалізації особистості, тобто, по особливостям культурних цінностей, їх динаміці можна судити про напрям економічної соціалізації особистості в економічному середовищі, але варто зазначити, що економічну культуру визначають не лише економічні але й інші групи цінностей [ 8 ].

Висновки. Отже, економічна культура $\epsilon$ цілісним явищем, створеним людиною, а також $\epsilon$ найважливішим засобом економічної соціалізації, оскільки долучає особистість до певних соціальних ролей, прагненню до самоудосконалення. У процесі економічної соціа- лізації люди засвоюють цінності, норми економічної культури та обирають ті 3 них, які більшою мірою дозволяють «вписатися» їм в систему соціально-економічних відносин, зберегти стабільність, досягнути своїх цілей, peaлізувати свої плани.

Між економічною культурою суспільства та економічною культурою особистості існує складний зв'язок і взаємна залежність, що проявляється, передусім, у слідуванні особистості принципам економічної культури суспільства. Економічна культура особистості може відповідати економічній культурі суспільства, опереджати іiі, але може й відставати від неї, заважати іїі розвитку [ 4 ].

Економічна культура особистості, ऑii становлення та розвиток також залежать від соціально-історичного контексту, рівня суспільного виробництва, традицій, менталітету.

Перспективним напрямом дослідження $є$ здійснення дослідження проблеми монетарної культури особистості як складової економічної культури, ïï структури та психологічних особливостей.

\section{Перелік використаних джерел:}

1. Анкундинова Е. В. Формирование экономической культуры личности / Е.В.Анкундинова / / Вестник ЧГПУ. -№9, 2009. - С.5-15.

2. Белинская Е. П Этническая социализация подростков/ Е. П. Белинская, Т. Г. Стефаненко -М. : Московсий психолого-социальный институт; Воронеж : Изд-во НПО «МОДЕКС», 2000. -208c.

3. Боровикова Т. В. Формирование основ экономичн- 
ской культуры школьников : дис. докт. пед. наук : 13.00.01/ Т. В. Боровикова. --Пермь, 2000. - 316.

4. Васильева Г. А. Формирование экономичнской культуры старшоеклассников в условиях дополнительного образования : дисс. канд. пед. наук: 13.00.01 / Г. А. Васильева. -- М., 2016. - 201с.

5. Гуревич П. С. Философия культуры / П. С. Гуревич. - [2-е изд.]. - М. : Аспект Пресс, 1995. - 218 с.

6. Зубіашвілі І. К., Мельничук Т. І. Психологічні особливості монетарної культури сучасної сім’ї / І. К. Зубіашвілі , Т. І. Мельничук // Fundamental and applied researches in practice of leading scientific schools, $2018-1$ (25), I. -Volume 25, Number 1. - С.135-139. - 0,5 д.а. ISSN 2313-7525 [Електронний ресурс] - Режим доступу: https://farplss.org/index.php/journal/issue/view/23

7. Ильин И. А. Философия Гегеля как учение о конкретности бога и человека /И. А. Ильин. - СПб, 1994. $312 \mathrm{c}$.

8. Кокшаров А. С. Влияние ценностей культуры на оценку ситуаций социального и экономического поведения/ А. С. Кокшаров/ / Альманах современной науки. №10, 2010. -С. 25-28.

9. Лебедева Н. М. Культура как фактор общественного прогресса/ Н. М. Лебедева,

А. Н. Татарко. М. : ЗАО «Юстцтнформ, 2009. - 409с.

10. Максакова В. И. Экономическая культура личности / И. Максакова. - М. : Наука, 1989. - 148 с.

11. Мид М. Культура и мир детства / М. Мид. - М. : Наука, 1988. - 429c.

12. Соціально-психологічні закономірності становлення економічної культури молоді: монографія / В.В.Москаленко, О.В.Лавренко, Н.М.Дембицька І.К.Зубіашвілі [та ін.]; за ред.. В.В.Москаленко - К.: Педагогічна думка, 2015. - 405 с.

13. Московичи С. Машина, творящая богов / С. Московичи; [пер. с фр. Т. П. Емельяновой, Г. Г. Дилигенского]. - М.: «Центр психологии и психотерапии», 1998. -560 c.

14. Моль А. Социодинамика культуры / А.Моль. М. : Прогресс, 1973. - 450c.
15. Мельничук Т. І. Соціально-психологічні закономірності економічної соціалізації молодої сім’ї: теоретико - емпіричне дослідження / Т. І. Мельничук // Психологічний часопис: збірник наукових праць / за ред. С. Д. Максименка. - № 3. - вип.13. - Київ: Інституту психології імені Г.С. Костюка Національної академії педагогічних наук України, 2018 . - с. 96-110- 0,5 д.а. [Електронний ресурс] - Режим доступу - http:// apsijournal.com/index.php/psyjournal/issue/view/13, DOI (Issue): https://doi.org/10.31108/2018vol13iss3

16. Радаев В. В. Экономическая. Социология : Курс лекций/ В. В. Радаев. - М. : Аспект-Пресс, 1999. - 367с. 17. Семенов В.С. Диалектика взаиморазвития общества, культуры, цивилизации /В.С. Семенов // Философия и общество. - Вып. № 2 (43), 2006. - С.68-95.

18. Сушков И. Р. Психологические отношения человека в социальной системе / И. Р. Сушков. - М. : Изд-во «Институт психологи РАН», 2006. - 412c.

19. Франк С. Л. Духовные основы общества / С. Л. Франк. - М. : Наука, 1992. - 312c.

20. Hofstede G. Culture's conseguences California Saje Pablication/G.Hofstede, 1980.

21. Thomas W. The polish peasant in Europe and America Cambridge/ W. Thoma, $1918-1920$.

\section{References (Transliteration):}

1. Ankundinova E. V. Formirovanie ehkonomicheskoyj kuljturih lichnosti / E. V. Ankundinova / / Vestnik ChGPU. - №9, 2009. - S.5-15.

2. Belinskaya E. P Ehtnicheskaya socializaciya podrostkov / E. P. Belinskaya, T. G. Stefanenko - M. : Moskovsiyj psikhologo-socialjnihyj institut; Voronezh : Izd -vo NPO «MODEKS», 2000. - 208s.

3. Borovikova T. V. Formirovanie osnov ehkonomichnskoyj kuljturih shkoljnikov : dis. dokt. ped. nauk : 13.00.01/ T. V. Borovikova. --Permj, 2000. - 316.

4. Vasiljeva G. A. Formirovanie ehkonomichnskoyj kuljturih starshoeklassnikov $\mathrm{v}$ usloviyakh dopolniteljnogo obrazovaniya : diss. kand. ped. nauk: 13.00.01 / G. A. 
Vasiljeva. -- M., 2016. -201s.

5. Gurevich P. S. Filosofiya kuljturih / P. S. Gurevich. - [2e izd.]. - M. : Aspekt Press, 1995.-218 s.

6. Zubiashvili I. K., Melnychuk T. I. Psykholohichni osoblyvosti monetarnoi kultury suchasnoi simi / I. K. Zubiashvili , T. I. Melnychuk // Fundamental and applied researches in practice of leading scientific schools, $2018-1$

(25), I. -Volume 25, Number 1. - S.135-139. - 0,5 d.a. ISSN 2313-7525 [Elektronnyi resurs] - Rezhym dostupu: https://farplss.org/index.php/journal/issue/view/23

7. Iljin I. A. Filosofiya Gegelya kak uchenie o konkretnosti boga i cheloveka / I. A. Iljin. - SPb, 1994. - 312s.

8. Koksharov A. S. Vliyanie cennosteyj kuljturih na ocenku situaciyj socialjnogo i ehkonomicheskogo povedeniya / A.

S. Koksharov / / Aljmanakh sovremennoyj nauki. - №10, 2010. -S. 25-28.

9. Lebedeva N. M. Kuljtura kak faktor obthestvennogo progressa / N. M. Lebedeva, A. N. Tatarko. - M. : ZAO «Yustctnform, 2009. - 409s.

10. Maksakova V. I. Ehkonomicheskaya kuljtura lichnosti /

I. Maksakova. - M. : Nauka, 1989. - 148 s.

11. Mid M. Kuljtura i mir detstva / M. Mid. - M. : Nauka, 1988. $-429 \mathrm{~s}$.

12. Socialjno-psikhologichni zakonomirnosti stanovlennya ekonomichnoï kuljturi molodi: monografiya V.V.Moskalenko, O.V.Lavrenko, N.M.Dembicjka I.K.Zubiashvili [ta in.]; za red.. V.V.Moskalenko - K.: Pedagogichna dumka, 2015. - 405 s.

13. Moskovichi S. Mashina, tvoryathaya bogov / S. Moskovichi; [per. s fr. T. P. Emeljyanovoyj, G. G. Diligenskogo]. - M.: «Centr psikhologii i psikhoterapii», 1998. $-560 \mathrm{~s}$.

14. Molj A. Sociodinamika kuljturih / A.Molj. M. : Progress, 1973. $-450 \mathrm{~s}$.

15. Melnychuk T. I. Sotsialno-psykholohichni zakonomirnosti ekonomichnoi sotsializatsii molodoi simi: teoretyko - empirychne doslidzhennia / T. I. Melnychuk // Psykholohichnyi chasopys: zbirnyk naukovykh prats / za red. S. D. Maksymenka. - № 3. - vyp.13. - Kyiv: Instytutu psykholohii imeni H.S. Kostiuka Natsionalnoi akademii pedahohichnykh nauk Ukrainy, 2018 . - s. 96-110- 0,5 d.a. [Elektronnyi resurs] - Rezhym dostupu - http:// apsijournal.com/index.php/psyjournal/issue/view/13, DOI (Issue): https://doi.org/10.31108/2018vol13iss3

16. Radaev V. V. Ehkonomicheskaya. Sociologiya : Kurs lekciyj / V. V. Radaev. - M. : Aspekt-Press, 1999. - 367s.

17. Semenov V. S. Dialektika vzaimorazvitiya obthestva, kuljturih, civilizacii / V. S. Semenov // Filosofiya i obthestvo. - Vihp. № 2 (43), 2006. - S.68-95.

18. Sushkov I. R. Psikhologicheskie otnosheniya cheloveka v socialjnoyj sisteme / I. R. Sushkov. - M. : Izd-vo «Institut psikhologi RAN», 2006. - 412s.

19. Frank S. L. Dukhovnihe osnovih obthestva / S. L. Frank. - M. : Nauka, 1992. - 312s.

20. Hofstede G. Culture's conseguences California Saje Pablication/G.Hofstede, 1980

21. Thomas W. The polish peasant in Europe and America Cambridge/ W. Thoma, $1918-1920$.

\section{Zubiashvily Irina}

Ph.D., senior scientist, of the Laboratory of Organizational and Social Psychology, H.S. Kostiuk Institute of Psychology of the National Academy of Educational Sciences of Ukraine, Kiev (Ukraine)

\section{ESSENCE OF ECONOMIC CULTURE AND ITS' ROLE IN THE ECONOMIC SOCIALI- ZATION}

\section{ABSTRACT}

In the article the results of a theoretical research of the essence of the economic culture of the person as the most important condition for its economic socialization are analyzed. The research made it possible to define culture as an integral set of specifically integrated means of creative activity, creating cultural values and being a universal form of human social develop- 
ment, determining its internal and external sociocultural and socio-conscious relations with the outside world. It has been revealed that economic culture is one of the special spheres of culture, representing, in a way, a projection of the economy onto the cultural sphere, although it can be argued that culture is a projection onto the economic sphere. The essential properties of economic culture are manifested in the fact that, first, they cover tendencies, norms that have arisen from the needs of the economy; secondly, the main channel of influence on the economy is not any behavior, but, above all, economic behavior; thirdly, the economic culture is more focused on the management of people's behavior with a view to increasing a material well-being. It is noted that in the conditions of transformation of the economic system of Ukraine, the role and importance of the economic culture of society in the economic socialization of the population increases, the result of which can be a new economic culture of the person. It is emphasized that by associating economic socialization with the process of the formation of the person's economic culture, it should be noted that culture is capable of transferring the values and attitudes of people from the spiritual to the material sphere, embodying values into reality. At the same time, it is important that the values governing the behavior and activities of the person in significant economic situations will affect the relations of economic subjects and, in general, the economic situation in the country. Nowadays, not creative work, but property and wealth, regardless of how they were obtained, are becoming increasingly important. It is proposed to draw attention to ensuring the moral content of many market values, the formation of a system of values of economic relations that rely on the human ones to avoid criminalization of the economy and economic relations, since the system of values included in the economic culture determines the process of economic socialization.

Keywords: culture, economic culture, economic socialization, personality, values, norms.

\section{Зубиашвили Ірина Константиновна}

Кандидат психологических наук, старший научный сотрудник лаборатории организационной и социальной психологии Института психологии имени Г. С. Костюка Национальной академии педагогических наук Украины, г. Киев (Украина)

\section{СУЩНОСТЬ ЭКОНОМИЧЕКОЙ КУЛЬТУРЫ ЛИЧНОСТИ И ЕЕ РОЛЬ В ЭКОНОМИЧЕСКОЙ СОЦИАЛИЗАЦИИ}

Аннотация. В статье анализируются результаты теоретического исследования сущности экономической культуры личности как важнейшего условия ее экономической социализации. Проведенное исследование дало возможность определить культуру как целостную совокупность специфически интегрированных способов творческой деятельности, создающих культурные ценности и являющиеся универсальной формой общественного развития человека, детерминируя ее внутренние и внешние социокультурные и социосознательные связи с окружающим миром. 
Выявлено, что экономическая культура - это одна из особенных сфер культуры, представляющая собой, своего рода, проекцию экономики на сферу культуры, хотя можно утверждать, что культура является проекцией на сферу экономики. Сущностные свойства экономической культуры проявляются в том, что во-первых, они охватывают тенденции, нормы, которые возникли из нужд экономики; вовторых, основным каналом влияния на экономику является не любое поведение, а прежде всего, экономическое; в третьих, экономическая культура в большей степени ориентирована на управление поведением людей с целью повышения материального благополучия. Отмечено, что в условиях трансформации экономической системы Украины увеличивается роль и значение экономической культуры общества в экономической социализации населения, результатом которой может быть новая экономическая культура личности. Подчеркивается, что связывая экономическую социализацию с процессом становления экономической культуры личности, следует отметить, что культура способна переносить ценности и установки людей из духовной сферы в материальную, воплощать ценности в действительность. При этом важным является то, что ценности, регулирующие поведение и деятельность личности в значимых экономических ситуациях, будут влиять на отношения субъектов экономики и, в целом, на экономическую ситуацию в стране. В наше время все более значимым становится не творческий труд, а собственность и богатство, независимо от того, каким способом они были получены. Предлагается обратить внимание на обеспечение нравственного содержания многих ценностей рынка, формирование системы ценностей экономических отношений, которые опираются на общечеловеческие, чтобы избежать криминализации экономики и экономических отношений, так как система ценностей, входящих в экономическую культуру, определяет процесс экономической социализации.

Ключевые слова: культура, экономическая культура, экономическая социализация, личность, ценности, нормы.

Дата отримання статті: 11.03.2019 Дата рекомендації до друку: 21.03.2019 Дата оприлюднення: 17.04.2019 